\title{
A Social and Economic Development Index: NUTS Ranking in Portugal
}

\author{
Francis co Diniz", Teres a Se que ira
}

Centre ofTransdisciplinaryDevelopmentStudies (CETRAD)/University ofTrás-os-M ontes and Alto Douro (UTAD), Vila Real, Portugal

\begin{abstract}
Once we accept the principle that development is a process which leads to changes in people's living conditions, regional development economists will always find it a challenge to try to define new ways of measuring the development level. The aim of this study is to calculate and to compare a Social and Economic Development Index (SEDI), regarding each concelho (NUTS IV) in Portugal. The SEDI is based on a set of variables-regarding demography, education, emp loyment, entrepreneurial structure, health, and housing conditions - present in each concelho. From there it will move forward to seeking for homogeneity patterns between the various concelhos, with recourse to the clusters mu ltivariate statistic method. Results point to there being clusters of concelhos highly differentiated, which suggests the need for a special care in setting up the spatial boundaries prior to its application to regional development policies and public management measures.
\end{abstract}

Keywo rds Social, Economic Development Index, Cluster Analysis, Public Management

\section{Introduction}

The aim of this study is, first of all, to present a new way of ranking Portuguese territorial units on the mainland, at the level of the concelhos ${ }^{\mathrm{i}}$, while making some considerations as to the position they occupy in what concerns social and economic development indicators. These will include variables other than those strictly related to economics. At a later stage, this study will be dealing with homogeneity relationships that might eventually exist among the different concelhos departing from a multivariate statistical model the clusters - obtained in the course of a process of several stages which begin with a hierarch ical method followed by a non-hierarchical one (K-means). Section 3 provides the methodological structure used in this study in order to facilitate the understanding of all the steps followed to achieve the aforementioned tasks.

Section 4 , in turn, presents an analysis of the results obtained as well as a description of the social and economic development level of all the different concelhos contemplated in this study, while ran king them and pointing out the variables or sets of variables which establish a connection between their development level and all the aspects which might account for it. These aspects are alsodealt with in greater detail in section 5 as an attempt to obtaining the clusters.

This study ends with some final remarks and considerations

* Corresponding author:

fdiniz@utad.pt (Francisco Diniz)

Published online at $\mathrm{http} / /$ journal.sapub.org/economics

Copyright (C) 2012 Scientific \& Academic Publishing. All Rights Reserved regarding its own shortcomings at the same time that it sets some guidelines for future research.

\section{Socio-Economic Development}

It is true that the concept of development implies a notion of futurity; it is also true that there can be no future without a clear knowledge of the past. From the beginning, any development process is associated with the idea of observing a certain situation which will be the starting point of that process. When subject to a deeper analysis, that idea will become the object of implementing a growth model closely linked with how it turns and changes into a quantitatively as well as qualitatively higher stage.

Although the actual per capita GDP is one of the indicators more frequently used to measure and compare economic growth/development processes, going on in different spatial areas, it has raised some severe criticism among researchers who have been pointing out its limited nature, especially because per capita GDP is but one of the many aspects of regional development. In its exclusive application this indicator ends up neglecting social aspects (such as access to education, health care and other living conditions) on the one hand, and other equally important variables that can be used to measure the economic performance of a given territory[1].

Since 1990, the Un ited Nations Develop ment Programme (UNDP) has been studying the recent history of human development evolution (especially after 1960) to the extent that it is primarily a process leading to each individual being able to widen the possibilities he or she is being given through accomplishing three major things: a long life, a good 
health, and knowledge that will grant him or her access to all the necessary requirements for a suitable living standard.

The concept of human development, however, does not exhaust itself in achieving these goals; it involves other equally important dimensions - even if they are not easy to achieve - which have to do with political, economic, and social freedom, but also creativeness, productiveness, and respect for basic human rights. As such, it points to two main features which always go hand in hand: namely the enhancing of individual abilities and the way people put them to use, whether for productive or recreational or even political, cultural, and social purposes. The lack of balance between these two aspects concerning human development can lead to serious frustration[2].

Therefore, gender issues were introduced in 1995. Since then, attention has been given to how differences of opportunity between genders could alter the ranking of countries vis-à-vis their development level. Likewise, the degree of participation of women in societies' political and economic life has been taken into account. Ever since 1997 special attention has been given to human poverty and the countries' situation has been measured on the assumption that poverty statute changes depending on how high the development level is or whether it is still at an early stage. Finally, in 1999 the technological achievement index was calculated for the purpose of defining leading countries, potential leaders and dynamic followers of new technologies [3].

All these approaches focused on a country as a territorial unit and despite including several variables other than GIP per capita they do not reflect a wide range of valences when the territorial analysis reaches a more restrict level[4]. The value added of this study lies, on the one hand, on a territorial analys is of a more local nature and, on the other hand, on a wider range of variables (demographic, educational, health care, economic/entrepreneurial, environmental, and quality of life) making roo $m$ for a better hierarchization of territorial units as far as their social and economic development level is concerned.

\section{Methodology}

The present study proposes a methodology which follows closely the one adopted by the UNDP in the Annual Report on Human Development in order to quantify social and economic development at a local level. It contemplates the integration of different dimensions (demographic, economic, social, and environmental) so that it can provide an integrated conceptual view on development.

The status quo model was the one chosen to systematize indicators. In fact, although it is usually assumed that development is best represented when different forms of indicators (pressure, status quoand answer) ${ }^{\mathrm{ii}}$, as well as the relationships between them, are analysed - only the former was taken into consideration, since the analys is in question concerns the status quo of development dynamics within the territory composed of the 278 concelhos in Mainland Portugal.

Table 1. SEDI Components $\mathrm{s}^{\mathrm{iii}}$

\begin{tabular}{|c|c|c|c|}
\hline Level & & Indicator & Description \\
\hline \multirow{4}{*}{ DEMOGRAPHY } & I1 & Demographic Growth & Residing population variation - \% bet ween 1991 and 2001 \\
\hline & $\mathrm{I} 2$ & $\begin{array}{l}\text { Natural Demographic } \\
\text { Growth }\end{array}$ & Natural growth rate $-\%$ in 2002 \\
\hline & I3 & $\begin{array}{l}\text { Migrant Demographic } \\
\text { Growth }\end{array}$ & $\begin{array}{l}\text { Residing population accordingto migrat ionsper residence concelho (in } \\
99 / 12 / 31 \text { ), per usual residence concelho in } 2001 / 3 / 12 \text { - Internal } \\
\text { Migration Balance }\end{array}$ \\
\hline & I4 & Fecundity rate & $\begin{array}{l}\text { Number of births per } 1.000 \text { fecund-age women (15-49 years of age) - } \\
\qquad 2002\end{array}$ \\
\hline \multirow{2}{*}{ EDUCATION } & I5 & Illiteracy & Illiteracy rate in $\%-2001$ \\
\hline & I6 & Higher Education & Population over 18 years of age with an university degree - \% in 2001 \\
\hline \multirow{4}{*}{ EMPLOYMENT } & I7 & Total Employment & Total employment rate- \% in 2001 \\
\hline & I8 & Total Unemployment & Total unemployment rate $-\%$ in 2001 \\
\hline & I9 & $\begin{array}{c}\text { Employment in non-primary } \\
\text { sector }\end{array}$ & Population employed in the non-primary sector- \% in 2001 \\
\hline & $\mathrm{I} 10$ & Employees and Pensioners & Employed population per pensioner -2001 \\
\hline \multirow{2}{*}{ ECONOMY } & I11 & Per head GNP & Per head GNP - 2001 \\
\hline & $\mathrm{I} 12$ & Purchasing Power & Purchasing Power Index - 2004 \\
\hline $\begin{array}{l}\text { ENT REPRENEURI } \\
\text { AL SECT OR }\end{array}$ & I13 & Entrepreneurial Structureiv & Entrepreneurial Index per Concelho - 2002 \\
\hline HEALT H & I14 & Healthv & Health Index per Concelho - 2002 \\
\hline HOUSING & $\mathrm{I} 15$ & Housing Conditionsvi & Housing Conditions Index per Concelho - 2001 \\
\hline
\end{tabular}

Source: Own calculations 
Bearing in mind both the aforementioned methodology and the data available for each concelho, the present SEDI is the result of 15 indicators representative of different development approaches (Table 1). Thus, as regards demography, four indicators were taken into consideration, which focus not only on the vitality but also on the human resources evolution dynamics taking place in each territory in terms of population growth - both natural and migrant and fertility rates. At the education level we expect to measure the population's qualifications with recourse to illiteracy rates while determining what percentage of the population has a university degree. From there, we move to other issues regarding employment, economy and the entrepreneurial sector departing from the seven indicators which can give an important contribution to a better knowledge of the population's living conditions in terms of both work and income. At this stage, we try to outline not only the territory's entrepreneurial structure profile but also the profile of a whole set of basic issues for the survival of the populations and the preservation of their sense of belonging and social cohesion. Finally, health and housing reinforce the social component presented by this index, seeking not only to assess the existing facilities and their corresponding accessibilities which, to a certain extent, show the social impact of local, economic and, demographic constraints.

Besides the indicator housing conditions also contemplates the environmental aspect since three features of this variable are included in the compound indicator so that social and economic aspects likely to influence resources' and the territories' environmental quality can be measured such as water and residues.

Another methodological aspect described concerns the way data was treated. In this case we chose the benchmarking type analysis using reference values as the most and the least favourable situation, ( $L s$ and $L i$, respectively). Thus, each indicator value calculated for each concelho undergoes a transformation according to the most or the least favourable value for the whole set of concelhos analysed. The result is a variation interval between zero and one. The reading of the values obtained gives room to understandingthe rel ative position of each concelhocompared to the one with the most favourable results, besides pointing to their inter- and intra-territorial cohesion levels.

The next step in our methodology was aggregating all the indexes. The same weighting ${ }^{1}$ was given to each of the 15 indicators seeking, albeit subjectively, that the final index would reflect the authors' perception as to each indicator's relative weight on development. Thus, the value of each indicator is first transformed as follows:

$$
\begin{aligned}
& \left(\mathrm{I}_{1,2, \ldots 278 ;}, \mathrm{I}_{21, \ldots 278 ;}, \cdots, \mathrm{I}_{15_{1,2,278}}\right)=(\mathrm{X}-\mathrm{Li}) /(\mathrm{Ls}-\mathrm{Li})(1) \\
& \text { where, } \\
& \text { (Ii: } \mathrm{i}=1,2, \ldots, 278)=\text { the concelho's indicator index } \\
& \mathrm{X}=\text { the concelho's indicator }
\end{aligned}
$$

\footnotetext{
${ }^{1}$ In this case the criterion adopted was the same used by the UNDP for the construction of the Human Development Index [13, 14].
}

$\mathrm{Li}=$ the indicator's least favourable value

Ls $=$ the indicator's most favourable value

Then the different indicators transformed are aggregated as follows:

$$
\text { SEDI }=\left({ }_{i=1, \ldots, 15^{15}} \Sigma \mathrm{I}_{\mathrm{i}} / 15\right)
$$

In order to be able to obtain clusters, namely hierarchical clusters, on a first approach we used both agglomerating and dividing techniques. According to these methods, the individuals- in this particular case the concelhos - are considered from the beginning as a cluster and later grouped according to their pro ximity or, on the contrary, allotted to a cluster and then divided into sub-groups depending on how distant they are from each other[11].

Several cluster connection methods have been tested using SPSS software in order to check whether they could produce similar results as suggested by Pestana and Gajeiro[12]. We were able to observe that the aggregation results obtained were very similar to those produced when using both Complete and Average Linkage(Within groups) methods. After using non-hierarchical K-means ${ }^{2}$ method, we were able to establish that the results thus obtained very much resembled Complete Linkage's ${ }^{3}$ and so we decided to choose it in order to compare these two types of methods.

\section{Results and Discussion}

Having described the methodology used to treat data concerning the variables chosen to deal with the various levels approached it was possible to calculate a social and economic development index - the SEDI - for each of the 278 concelhos in Mainland Portugal. Based on this index and on the values obtained for each concelho, we will first look at the hierarchical position of the concelhos explaining their development level by their place in the ranking in relation to the 15 indicators which compose the final index.

The SEDI presents a value oscillating between a little under $1 / 4$ and a maximu $m$ of appro ximately $2 / 3$. The variation coefficient value is not significant since the standard deviation is about $20 \%$ of the mean value. The concelho of Vinhais shows the lowest index value $(0.2364)$, which means it is only $24 \%$ short of having the worst results of all the indicators.Lisbon in turn occupies the top place in the ranking reaching a threshold of 0.6609 , which, nevertheless, places this concelho 34 points short of reaching an optimal position. The SEDI concentration is at 40 points, moving less away from the worst position than fro $m$ the most favourable one. (Annexe I, Table I.1)

\footnotetext{
2 K-means is a non-hierarchical method which, as such, does not require a similitude/distance matrix calculation and is directly applied to the original data. It starts with the initial partition of individuals into a previously defined number of clusters and consists of trans ferring an individual to the cluster whose centre is nearer [15].

3 The Complete Linkage criterion is a process by which the distance between two groups is defined as the distance between its most distant or least similar elements. The group is then described as a set of elements where each element resembles more all the other elements within the group than any of the other elements of the remaining groups [15].
} 
The two concelhos with a SEDI below 0.25 (about 1\%) Vinhais and Mértola -, are both located in the hinterland and on the border with Spain. The 16 concelhos with a SEDI between 0.25 and 0.3 , have in common the fact that they all lie several kilo metres inland. And when the index goes up to 0.35 , of the 46 concelhos in that interval (appro ximate ly $17 \%$ of the total under analysis), only Odemira lies on the coast, more precisely in Alentejo (Figure 1).

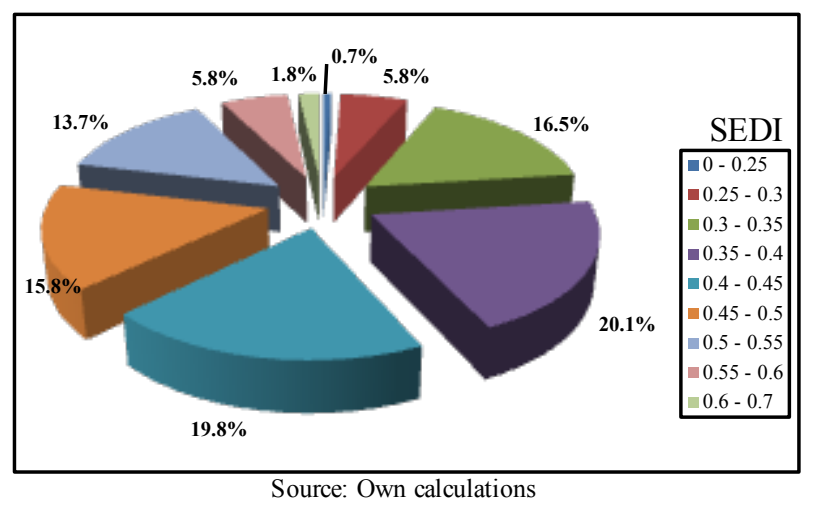

Figure 1. Per cent Distribution of the Concelhos According to SEDI Levels

With the greatest number of concelhos (56 of the 278 under analys is), the development level between 0.35 and 0.4 includes only Alcácer do Sal, Grândola, A ljezur and Castro Marim, all of them in the south, namely on the coastal strip of Alentejo and Algarve. The remain ing 52 concelhos, as we have already seen, are located further in land.

Once the analysis of the first half of the interval between SEDI maximum and minimum values has been completed it is important to point out again the most important feature observed so far and that is the fact that all the spaces lie away from the coast.

As we move over 0.05 up on the SEDI ranking, the concelhos on the coast start to show a slightly better performance. It is the case of Caminha in the north, Tavira and Vila do Bispo in the Algarve, and Santiago do Cacém in Alentejo. It should also be pointed out that the majority of the costal concelhos in this interval are located in the centre of the country (Lourinhã, Peniche, Óbidos, Nazaré, Pombal, Cantanhede, Mira and, Murtosa). The remaining 43 concelhos are all located in the interior of the country which remains the major space of this development level.

With a SEDI between 0.45 and 0.5 , the coastal strip still has more concelhos north of the river Tagus than, for instances, the Algarve where only Olhão, Silves and Vila Real de Santo António have reached that score. Although the distribution in this development level is very similar in percentage terms to the distribution observed in the previous level, as far as coastal concelhos are concerned (about 20\%), the great difference lies in the location of inland concelhos since their performance as regards this development level, is beginning to be closer to the former's.

That is even more striking when we move 5 points up in the SEDI; then the coastal concelhos and the ones located in adjoining areas achieve the best performance for the first time. Yet it is possible to find in the same development threshold such concelhos as Viseu, Guarda and Évora, where there is a strong urban concentration despite their being far away from the coast. If to this axis we add other inland cities with slightly lower SEDI, we may conclude that these territories play an important role in polycentric development defined as a regional develop ment policy by the EU[16].

Finally, the country's two main urban centres can be found in SEDI'S two last levels. With an index between 0.55 and 0.6 we have those concelhos which include the cities of Aveiro, Braga, Coimbra, Faro, and Porto, as well as other territorial units belonging to Lisbon and O'Porto metropolitan areas, such as Odivelas, Seixal, and Vila Franca de Xira, ( belonging to the former) and Maia, and Vila Nova de Gaia (belonging to the latter). At the SEDI top level we find the concelhos in Lisbon metropolitan area and Albufeira, in the Algarve, which is an exception (Map 1).

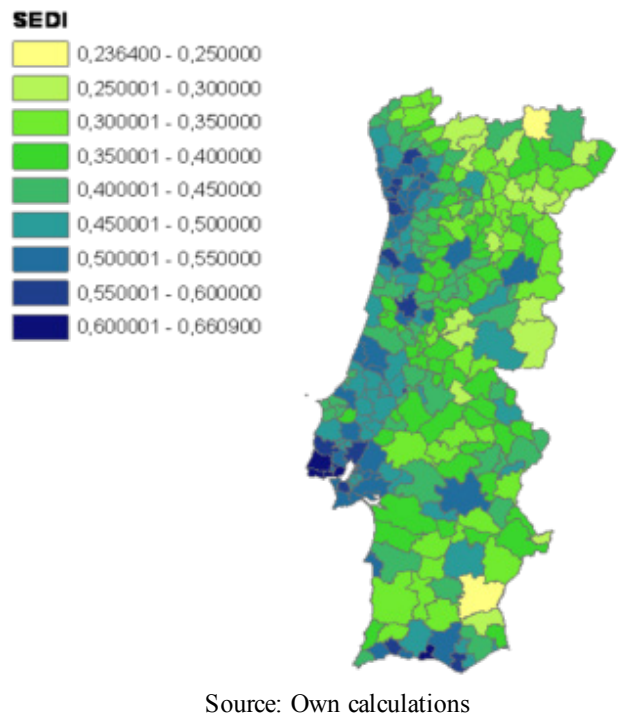

Map 1. SEDI forthe Concelhos of Mainland Portugal

In order to complete our first analysis of how the concelhos position themselves regarding SEDI we will look in detail at the 15 indicators which served as the basis of our compound index. As mentioned before, these have to do with variables grouped according to several levels: Demography; Education; Emp loyment; Economy; Entrepreneurial Sector; Health; Housing.

Starting with demography, it seems that a little over half of the concelhos in Mainland Portugal register a negative demographic growth, especially in the hinterland territorial units near or on the border. In turn, the areas with a higher population growth are located on the coast, namely in Lisbon and O'Porto metropolitan areas and in some concelhos of the Algarve. As if contradicting the idea that inland areas are becoming depopulated, the concelhos of Vila Real, Viseu, and Guarda register positive demographic growth rates, which reinforce the aforementioned polycentrism.

Natural growth is a phenomenon more likely to occur in the north than in the south for a number of reasons but mainly due to the positive contribution of that half of the 
country lying to the north and clos er to the coast. Similarly to what happens with demographic growth, generally speaking, in the inland regions near the border natural growth rates are relatively lower.

The migrant balance indicates that the two big metropolitan areas, with the exception of their respective main cities, Lisbon and O'Porto, do indeed attract more people. Likewise, the Algarve as well as some concelhos on the coast in central Portugal register some very positive values as concerns this issue (Map 2).

In what concerns education and based on the two indicators chosen - Illiteracy and Higher Education - it may be said that the former has a more even distribution all over the country, although there are still some serious problems in the south, namely in BaixoAlentejo. On the other hand, the biggest contribution to SEDI in terms of the Population with an University Degree Indicator definitely comes from those concelhos where there are universities and polytechnic schools (Map 3).

Total employment rate gives a positive contribution to SEDI in most of the coastal strip areas, with the exception of some concelhos to the north, like Mira, Figueira da Foz, Cantanhede, Murtosa, and Pombal in the central region and some in the Algarve and Alentejo coastal strip. Central Alent ejo also shows very positive values. The unemployment rate is particularly high in A lentejo, a predicament confirmed by the weight the number of pensioners has in the whole of the hinterland from the north to the south and in the whole of the Alentejo (Map 4).
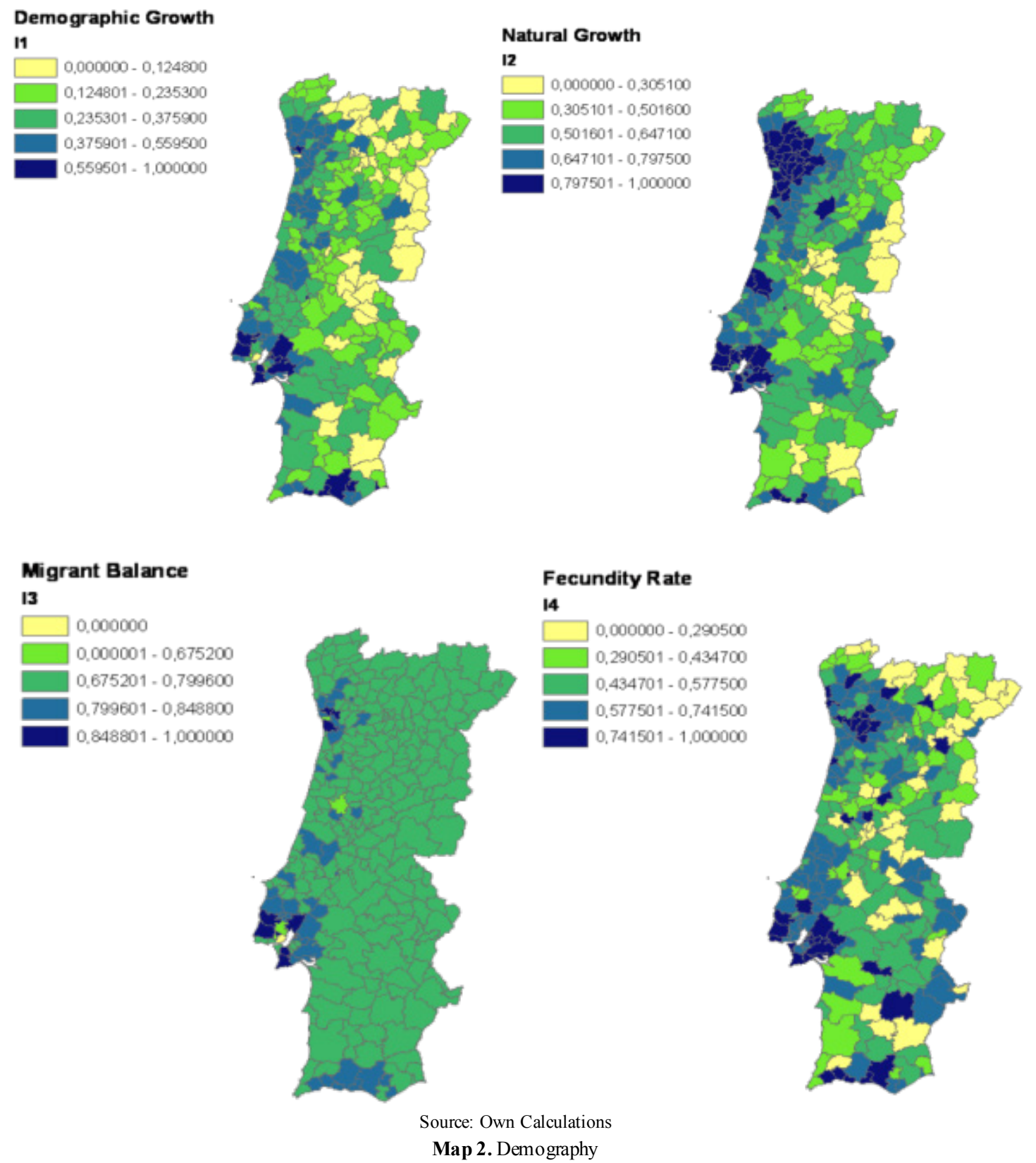

Map 2. Demography 


\section{Illiteracy Rate}

15

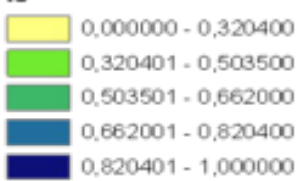

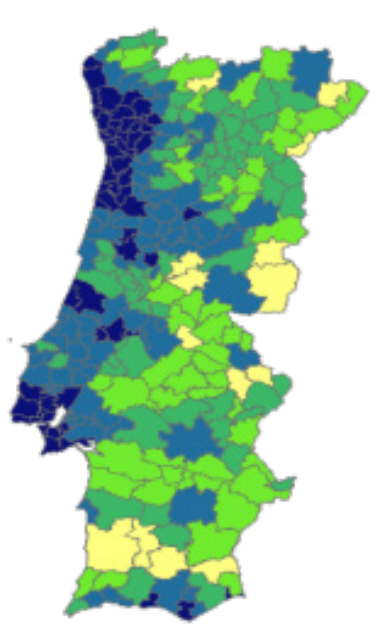

Population with an University Degree

16

$\square, 0,002600-0,086900$ $0,086901 \cdot 0,165200$ $0,165201 \cdot 0.287000$ $0,287001-0,538300$ $0,538301-1,000000$

Source: Own Calculations

Map 3. Education

\section{Total Employment Rate}

17

$0,000000-0,442200$

$0,442201-0,603300$

$0,603301 \cdot 0.716700$

$0,716701-0,818200$

$0,818201-1,000000$

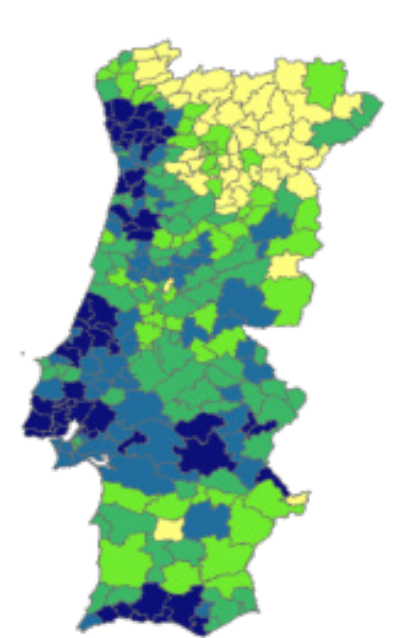

Employment in non-primary Sector

19

$0,000000-0,424500$

$0,424501-0,642300$

$0.642301-0.786900$

$0.786901-0,910100$

$0,910101-1,000000$
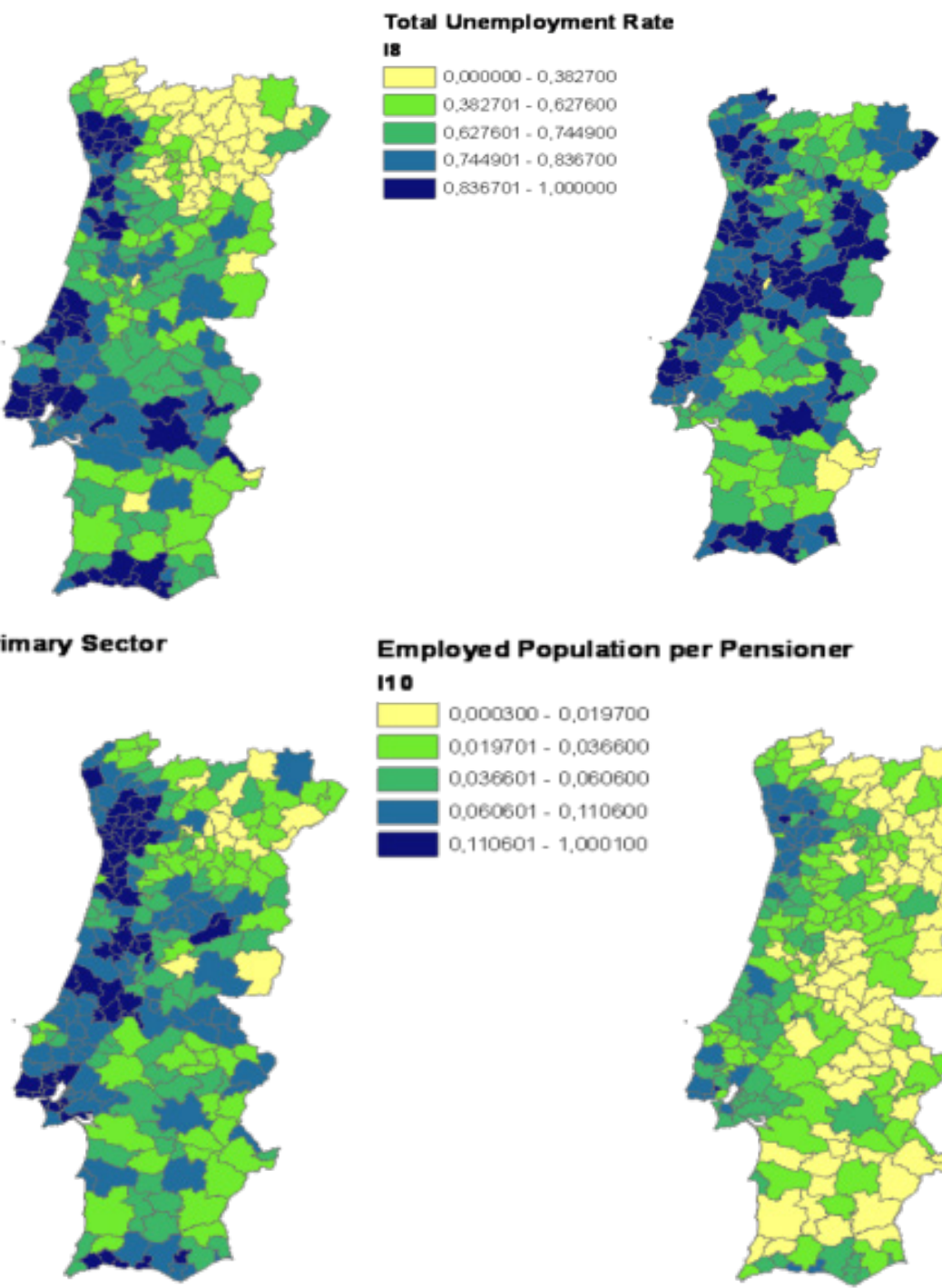

\section{Employed Population per Pensioner}

110
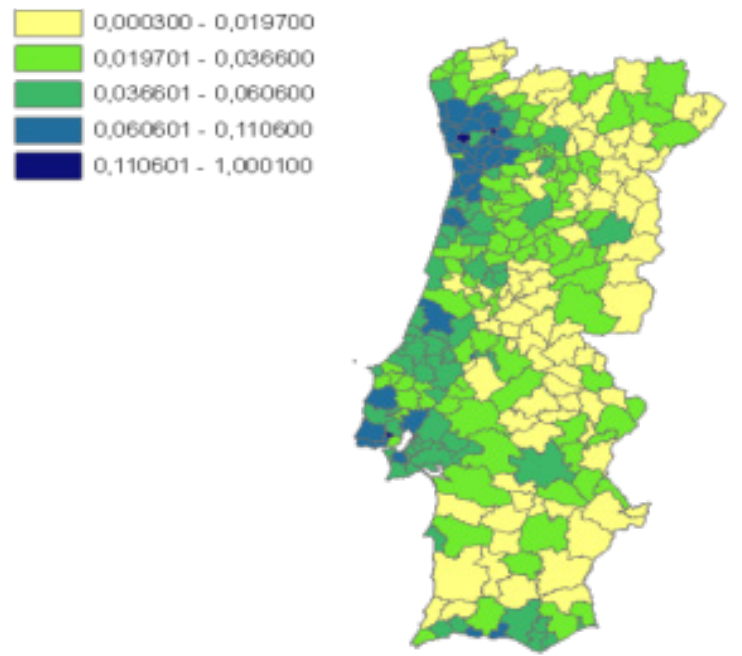

Source: Own Calculations

Map 4. Employment 
A look at the per head GNP indicator explains how the economy is concentrated in Lisbon and O'Porto metropolitan areas. There are, however, a few exceptions. Miranda doDouro, and Castro Verde, in the interior of the country, are among the concelhos with the best performance concerning this indicator. Responsible for this excellent performance are, no doubt, the dams and the production of electrical power in the former and the mining industry in the latter. It is also worth mentioning the fact that petrochemical industry is based on the concelho of Sines, in the Alentejo coastal strip, which makes this indicator so interesting and contributes in a very positive way to its respective SEDI. Once again, almost the whole of the hinterland, especially the regions near the border, reach low levels regard ing this indicator. Likewise, the Purchasing Power is stronger in the above mentioned metropolitan areas as well as in the Algarve. As a consequence of the tertiarization of their economies and the presence there of some universities, Bragança, Portalegre, Évora, and Beja in the hinterland present quite interesting living standards (Map 5).

\section{Purchasing Power}

112
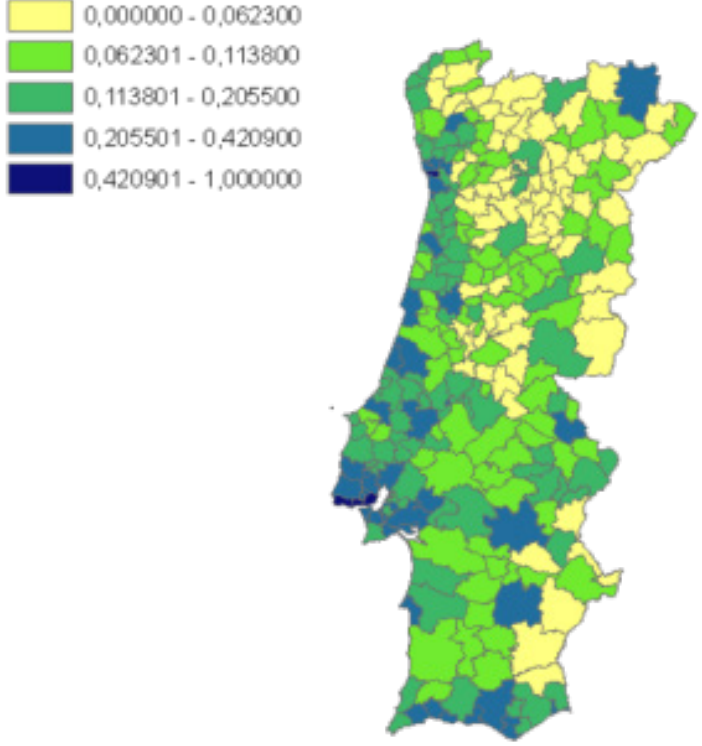

Source: Own Calculations

Map 5. Economy
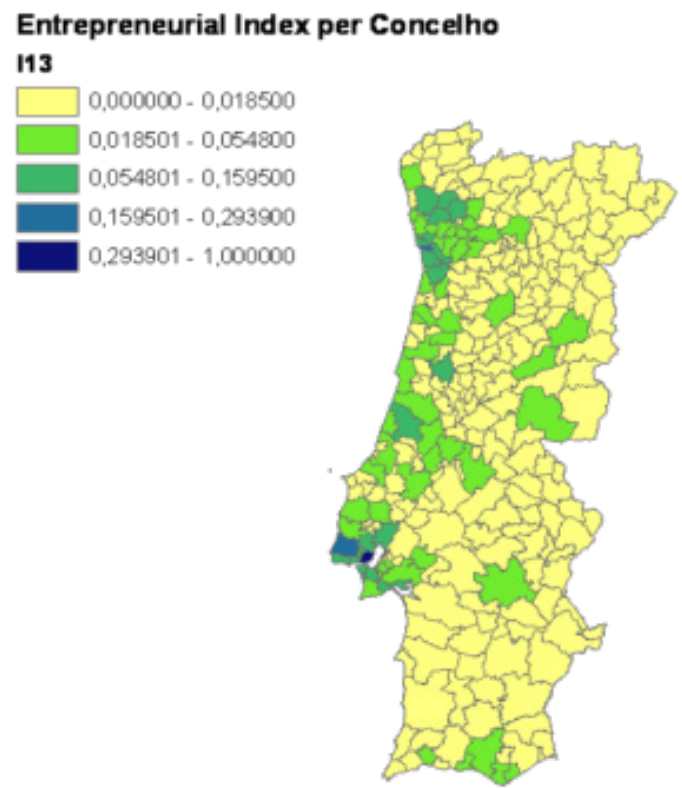

Source: Own Calculations

Map 6. Entrepreneurial Sector 
The entrepreneurial index per concelho, which includes four indicators: a) Business firms based on the region; b) Partnerships based on the region; c) Personnel working in partnerships based on the region; and, d) turnover of partnerships based on the region, again points to a stronger concentration of economic activity in O'Porto and Lisbon metropolitan areas. These two areas along with Leiria region, the Algarve coastal strip, and some urban centres in the interior of the country emphasize the rest of the country's lack of entrepreneurship (Map 6).
When we look at the health indicator we come upon some very interesting conclusions. The concelhos in O'Porto and Lisbon metropolitan areas located around these two cities present several weaknesses and this is a situation which also occurs in the Algarve and in the vicinity of Coimbra. The regions along the border, with the exception of Vimioso in the north, Castelo Branco in the centre, and the boarder concelhos of Alto Alentejo in the south, have considerable needs when it comes to infrastructure, equipment and human capital (Map 7).

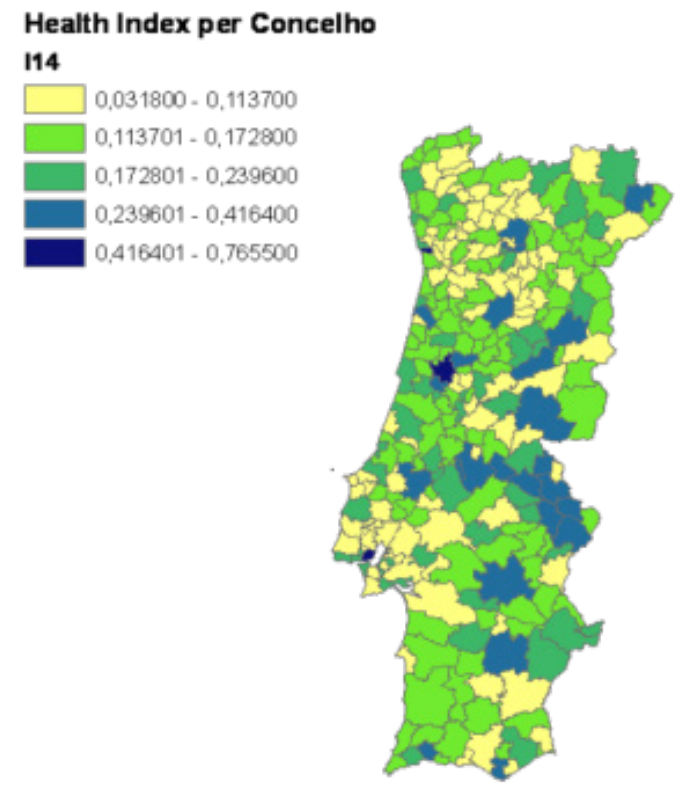

Source: Own Calculations

Map 7.Health

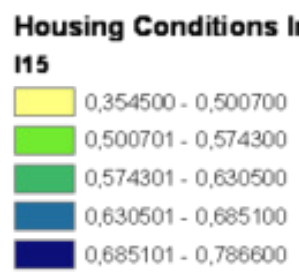

Housing Conditions Index per Concelho

115

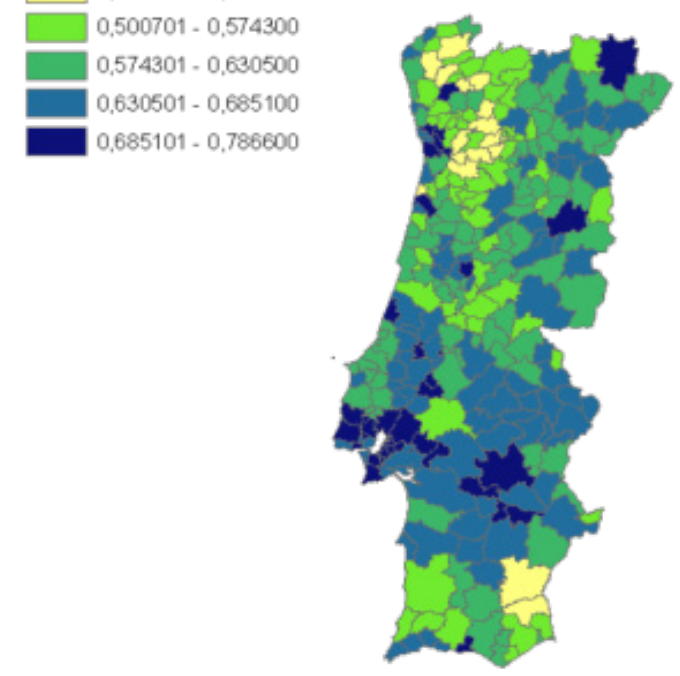

Source: Own Calculations

Map 8. Housing 
Finally, the analysis of the housing conditions shows that the concelhos situated in the interior north and not very far from the coast have more weaknesses than the ones further inland, with the exception of Mértola, and Alcoutim, in BaixoAlentejo, and Algarve, respectively. The latter actually face great difficulties as regards housing conditions. Although living conditions are much better in both metropolitan areas, it is already possible to enjoy some good conditions in terms of comfort in several concelhos of the interior of the country (Map 8).

\section{Cluster Analysis}

In order to be able to analyse the SEDI'S several components we tried to group the concelhos into clusters, which as described by López[17] is a multivariate statistic method whose main object is "... revelarconcentraciones en los datosparasuagrupamientoeficiente en clusters (o conglomerados) segúnsuhomogeneidad"vii .

As it was already mentioned in section 2, our first intention was to obtain hierarchical clusters. Based on our findings we concluded that aggregation results were very similar whether we used the Complete or the Average Linkage (W ithin groups) method.

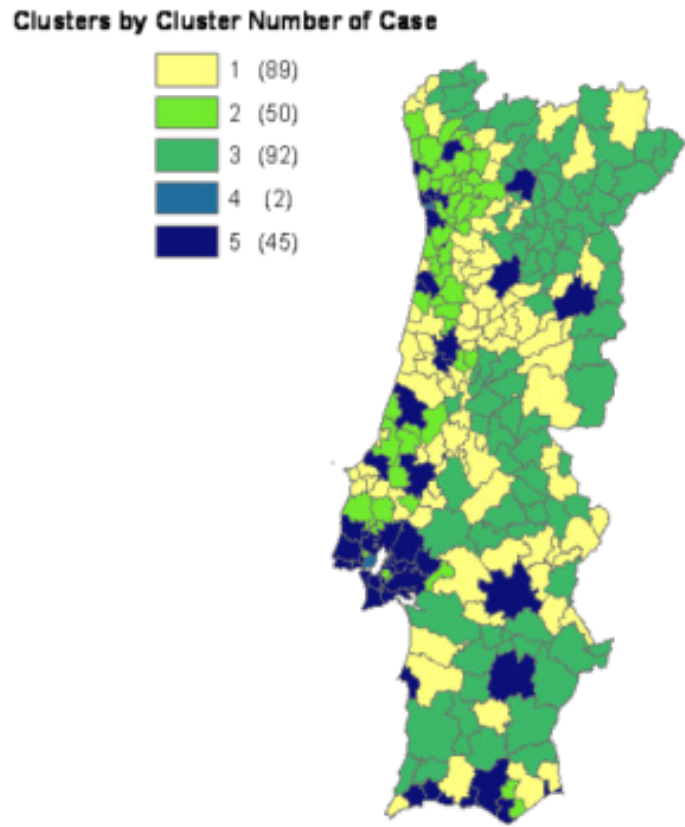

Source: Own Calculations

Map 9. The concelhos grouped into clusters (K-means)

Table 2. Summary of variable descriptive st at istics per cluster

\begin{tabular}{|c|c|c|c|c|c|c|c|c|c|}
\hline \multirow{2}{*}{ Variable } & \multirow{2}{*}{ Cluster } & \multirow{2}{*}{$\mathrm{N}$} & \multirow{2}{*}{ Mean } & \multirow{2}{*}{ Std. Deviation } & \multirow{2}{*}{ Std. Error } & \multicolumn{2}{|c|}{ 95\% Conf Int. f. Mean } & \multirow{2}{*}{ Minimum } & \multirow{2}{*}{ Maximum } \\
\hline & & & & & & Lower B. & Upper B. & & \\
\hline I1 & 1 & 89 & 0,257 & 0,071 & 0,008 & 0,242 & 0,272 & 0,077 & 0,484 \\
\hline $\mathbf{I 2}$ & 1 & 89 & 0,59 & 0,082 & 0,009 & 0,573 & 0,607 & 0,372 & 0,779 \\
\hline I3 & 1 & 89 & 0,790 & 0,006 & 0,001 & 0,789 & 0,791 & 0,773 & 0,806 \\
\hline I4 & 1 & 89 & 0,511 & 0,146 & 0,016 & 0,481 & 0,542 & 0,240 & 1,000 \\
\hline I5 & 1 & 89 & 0,657 & 0,111 & 0,012 & 0,634 & 0,681 & 0,401 & 0,880 \\
\hline I6 & 1 & 89 & 0,151 & 0,073 & 0,008 & 0,136 & 0,166 & 0,019 & 0,418 \\
\hline 17 & 1 & 89 & 0,662 & 0,112 & 0,012 & 0,638 & 0,686 & 0,325 & 0,888 \\
\hline I8 & 1 & 89 & 0,782 & 0,092 & 0,010 & 0,763 & 0,802 & 0,520 & 0,959 \\
\hline I9 & 1 & 89 & 0,786 & 0,101 & 0,011 & 0,765 & 0,807 & 0,550 & 0,964 \\
\hline I10 & 1 & 89 & 0,028 & 0,008 & 0,001 & 0,027 & 0,030 & 0,010 & 0,059 \\
\hline I11 & 1 & 89 & 0,118 & 0,081 & 0,009 & 0,101 & 0,135 & 0,000 & 0,746 \\
\hline I12 & 1 & 89 & 0,109 & 0,048 & 0,005 & 0,099 & 0,119 & 0,000 & 0,242 \\
\hline I13 & 1 & 89 & 0,009 & 0,007 & 0,001 & 0,008 & 0,011 & 0,001 & 0,039 \\
\hline I14 & 1 & 89 & 0,159 & 0,058 & 0,006 & 0,147 & 0,171 & 0,072 & 0,376 \\
\hline
\end{tabular}




\begin{tabular}{|c|c|c|c|c|c|c|c|c|c|}
\hline I1 & 2 & 50 & 0,431 & 0,082 & 0,012 & 0,408 & 0,454 & 0,316 & 0,752 \\
\hline I2 & 2 & 50 & 0,813 & 0,105 & 0,015 & 0,783 & ',843 & 0,558 & 1,000 \\
\hline I3 & 2 & 50 & 0,801 & 0,018 & 0,003 & $\backslash 0,796$ & 0,806 & 0,766 & 0,864 \\
\hline I4 & 2 & 50 & 0,657 & 0,120 & 0,017 & 0,623 & 0,691 & 0,395 & 0,892 \\
\hline I5 & 2 & 50 & 0,821 & 0,070 & 0,010 & 0,802 & 0,841 & 0,673 & 0,951 \\
\hline I6 & 2 & 50 & 0,166 & 0,070 & 0,010 & 0,146 & 0,186 & 0,045 & 0,346 \\
\hline 17 & 2 & 50 & 0,805 & 0,106 & 0,015 & 0,775 & 0,835 & 0,564 & 1,000 \\
\hline I8 & 2 & 50 & 0,853 & 0,078 & 0,011 & 0,831 & 0,875 & 0,582 & 1,000 \\
\hline 19 & 2 & 50 & 0,915 & 0,058 & 0,008 & 0,899 & 0,932 & 0,750 & 0,999 \\
\hline I10 & 2 & 50 & 0,100 & 0,187 & 0,026 & 0,046 & 0,153 & 0,025 & 1,000 \\
\hline I11 & 2 & 50 & 0,135 & 0,048 & 0,007 & 0,121 & 0,148 & 0,050 & 0,237 \\
\hline I12 & 2 & 50 & 0,124 & 0,047 & 0,007 & 0,110 & 0,137 & 0,041 & 0,287 \\
\hline I13 & 2 & 50 & 0,029 & 0,023 & 0,003 & 0,022 & 0,035 & 0,004 & 0,094 \\
\hline I14 & 2 & 50 & 0,113 & 0,039 & 0,006 & 0,101 & 0,124 & 0,058 & 0,239 \\
\hline I15 & 2 & 50 & 0,595 & 0,068 & 0,010 & 0,576 & 0,615 & 0,474 & 0,719 \\
\hline I1 & 3 & 92 & 0,134 & 0,068 & 0,007 & 0,120 & 0,148 & 0,000 & 0,354 \\
\hline 12 & 3 & 92 & 0,421 & 0,150 & 0,016 & 0,390 & 0,452 & 0,000 & 0,720 \\
\hline I3 & 3 & 92 & 0,788 & 0,002 & 0,000 & 0,788 & 0,789 & 0,782 & 0,794 \\
\hline I4 & 3 & 92 & 0,387 & 0,177 & 0,018 & 0,350 & 0,424 & 0,000 & 0,801 \\
\hline 15 & 3 & 92 & 0,452 & 0,133 & 0,014 & 0,425 & 0,480 & 0,000 & 0,669 \\
\hline I6 & 3 & 92 & 0,083 & 0,038 & 0,004 & 0,075 & 0,091 & 0,003 & 0,199 \\
\hline 17 & 3 & 92 & 0,488 & 0,157 & 0,016 & 0,455 & 0,521 & 0,000 & 0,770 \\
\hline I8 & 3 & 92 & 0,687 & 0,158 & 0,016 & 0,654 & 0,719 & 0,000 & 0,959 \\
\hline 19 & 3 & 92 & 0,577 & 0,165 & 0,017 & 0,543 & 0,612 & 0,000 & 0,952 \\
\hline I10 & 3 & 92 & 0,014 & 0,007 & 0,001 & 0,013 & 0,016 & 0,000 & 0,031 \\
\hline I11 & 3 & 92 & 0,089 & 0,069 & 0,007 & 0,074 & 0,103 & 0,008 & 0,503 \\
\hline I12 & 3 & 92 & 0,058 & 0,027 & 0,003 & 0,052 & 0,063 & 0,001 & 0,147 \\
\hline I13 & 3 & 92 & 0,003 & 0,002 & 0,000 & 0,002 & 0,003 & 0,000 & 0,013 \\
\hline I14 & 3 & 92 & 0,139 & 0,059 & 0,006 & 0,127 & 0,151 & 0,032 & 0,416 \\
\hline I15 & 3 & 92 & 0,594 & 0,057 & 0,006 & 0,583 & 0,606 & 0,433 & 0,704 \\
\hline I1 & 4 & 2 & 0,074 & 0,019 & 0,014 & $-0,099$ & 0,247 & 0,060 & 0,088 \\
\hline I2 & 4 & 2 & 0,624 & 0,033 & 0,024 & 0,324 & 0,923 & 0,600 & 0,647 \\
\hline $\mathbf{I 3}$ & 4 & 2 & 0,207 & 0,292 & 0,207 & $-2,418$ & 2,832 & 0,000 & 0,413 \\
\hline I4 & 4 & 2 & 0,600 & 0,156 & 0,110 & $-0,800$ & 2,000 & 0,490 & 0,710 \\
\hline I5 & 4 & 2 & 0,940 & 0,030 & 0,021 & 0,672 & 1,209 & 0,919 & 0,961 \\
\hline I6 & 4 & 2 & 0,848 & 0,103 & 0,073 & $-0,073$ & 1,770 & 0,776 & 0,921 \\
\hline 17 & 4 & 2 & 0,761 & 0,100 & 0,071 & $-0,135$ & 1,658 & 0,691 & 0,832 \\
\hline I8 & 4 & 2 & 0,679 & 0,101 & 0,071 & $-0,229$ & 1,586 & 0,607 & 0,750 \\
\hline 19 & 4 & 2 & 0,997 & 0,002 & 0,001 & 0,983 & 1,012 & 0,996 & 0,999 \\
\hline I10 & 4 & 2 & 0,030 & 0,007 & 0,005 & $-0,029$ & 0,089 & 0,025 & 0,034 \\
\hline I11 & 4 & 2 & 0,654 & 0,204 & 0,145 & $-1,184$ & 2,491 & 0,509 & 0,798 \\
\hline I12 & 4 & 2 & 0,832 & 0,238 & 0,168 & $-1,306$ & 2,969 & 0,664 & 1,000 \\
\hline I13 & 4 & 2 & 0,647 & 0,499 & 0,353 & $-3,839$ & 5,133 & 0,294 & 1,000 \\
\hline I14 & 4 & 2 & 0,677 & 0,035 & 0,025 & 0,361 & 0,994 & 0,652 & 0,702 \\
\hline I15 & 4 & 2 & 0,654 & 0,007 & 0,005 & 0,594 & 0,713 & 0,649 & 0,658 \\
\hline I1 & 5 & 45 & 0,498 & 0,167 & 0,025 & 0,448 & 0,548 & 0,161 & 1,000 \\
\hline I2 & 5 & 45 & 0,814 & 0,087 & 0,013 & 0,788 & 0,840 & 0,629 & 0,983 \\
\hline I3 & 5 & 45 & 0,806 & 0,062 & 0,009 & 0,787 & 0,825 & 0,654 & 1,000 \\
\hline I4 & 5 & 45 & 0,722 & 0,134 & 0,020 & 0,682 & 0,762 & 0,414 & 0,997 \\
\hline I5 & 5 & 45 & 0,864 & 0,087 & 0,013 & 0,838 & 0,890 & 0,676 & 1,000 \\
\hline I6 & 5 & 45 & 0,389 & 0,158 & 0,024 & 0,341 & 0,437 & 0,187 & 1,000 \\
\hline 17 & 5 & 45 & 0,817 & 0,085 & 0,013 & 0,791 & 0,842 & 0,575 & 0,990 \\
\hline I8 & 5 & 45 & 0,771 & 0,073 & 0,011 & 0,749 & 0,793 & 0,607 & 0,939 \\
\hline 19 & 5 & 45 & 0,935 & 0,057 & 0,008 & 0,918 & 0,953 & 0,812 & 1,000 \\
\hline I10 & 5 & 45 & 0,059 & 0,017 & 0,003 & 0,054 & 0,065 & 0,028 & 0,106 \\
\hline I11 & 5 & 45 & 0,223 & 0,141 & 0,021 & 0,181 & 0,265 & 0,105 & 1,000 \\
\hline I12 & 5 & 45 & 0,273 & 0,091 & 0,014 & 0,246 & 0,300 & 0,145 & 0,589 \\
\hline I13 & 5 & 45 & 0,055 & 0,048 & 0,007 & 0,041 & 0,070 & 0,006 & 0,215 \\
\hline I14 & 5 & 45 & 0,200 & 0,118 & 0,018 & 0,164 & 0,235 & 0,078 & 0,765 \\
\hline I15 & 5 & 45 & 0,684 & 0,044 & 0,007 & 0,670 & 0,697 & 0,599 & 0,787 \\
\hline
\end{tabular}

Since the non-hierarchical K-means method implies establishing a number of clusters right from the onset, we decided to make a previous analysis using Complete Linkage to establish that number. The criteria applied were the distance between clusters and the R-square. The distance criterion showed that we could retain 5 to 10 clusters for it is when the slope of the straight line uniting the distance between two clusters is bigger. When to this analysis we added the R-square criterion we observed that the 5 cluster solution retains $75,9 \%$ of the total variability. In terms of 
getting a minimum number of clusters, the 5 cluster solution seems to us the eligible one since, from the beginning, it retains a significant percentage of the total variability.

In table II. 1 of the annexe we produce the results obtained through non-hierarchical K-means method. K-means will serve as the basis of our analysis for, in general, non-hierarchical methods provide a more accurate classification of the subjects. Map 9 and Table 2 show the clusters obtained through this method, namely their geographical distribution and the variable descriptive statistics.

The variance analysis presented in annexe II. 5 allowed us to identify those variables leading to a division per cluster as well as their relative importance. ${ }^{\text {viii }}$.This way it was possible to establish that I12 (Purchasing Power) is the variable which contributes most to cluster division followed by $\mathrm{I} 3$ (Migrant Demographic Growth), and I13 (Entrepreneurial Structure), I5 (Illiteracy), I1 (Demographic Growth), I2 (Natural Demographic Growth), I6 (Higher Education) and I9 (Employment in the Non-primary Sector), and also by I7 (Total Employment), I4 (Fecundity Rate), I14 (Health), and I1 1 (per head GNP); and finally by I15 (Hous ing Conditions), I8 (Total Unemployment), and I10 (Employees and Pensioners).

When we cross-reference this information with the one in Table 2 consisting of a summary of variable descriptive statistics per cluster, mean statistic tests ${ }^{\text {ix }}$ and the map previously produced, the following may be observed:

Cluster 4, composed of the cities of Lisbon and O'Porto dominates regarding such indicators as Purchasing Power (I12), Entrepreneurial Structure Dynamism, (I13), Population with an University Degree (I6), Health Indicators (I14), and Per Head GNP (I11), immediately followed by cluster 5 - which includes, a mong others, the most important urban nuclei - in relation to the same indicators.

Cluster 4 also has the lowest migrant demographic growth (I3), andcluster 5 the highest demographic growth (I1).

Cluster 3 is representative of the great majority of the inland concelhos and it is different from the rest for its low level of employment and high illiteracy rate which reflect themselves on I7 and I5; it also has the lowest level of both population with an university degree (I6) and of purchasing power (I12).

Cluster 2, including a set of concelhos near the coast stands out, among other reasons, for its positive behaviour in such aspects as unemployment and demographic growth with a repercussion on I8 and I1, a relative entrepreneurial dynamis m(I13), only overcome by clusters 4 and 5, and for a rather favourable emp loyed population per pensioner ratio (I10).

Finally, cluster 1, including 89 concelhos spreading throughout the territory, with a relative concentration in the centre occupies an intermediate position in relation to most of the indicators.

The intrinsic homogeneities of each cluster as well as the inter-cluster differences found are the result of not only the social and economic specificities already existing in each cluster but also of regional development policies implemented in Portugal after the country has joined the European Union. These policies increased the importance of coastal towns against rural areas and the hinterland which may be observed in the dichotomies between clusters 4 and 5 versus 1 and 3.

\section{Final Remarks and Policy / Managerial Implications}

The use of cluster techniques to analyse the several indicators which compose the SEDI in each concelho only stressed the notion that the concelhoson the coast and the ones in the interior of the country, separated by an intermediate central zone, have different characteristics and that the same situation occurs when we look at the group of concelhos which include the main towns and the concelhos around themand the one formed by the two big cities, Lis bon and O'Porto.

The simple exercise of overlapping the NUT III regions map and the map of the concelhos produced would clearly show the great asymmetries in terms of development within each NUT III. These asymmetries would be even bigger if we were to overlap the NUT III regions map with the map of the territory regarding NUT II. We believe these considerations to be particularly important for the defin ition of new development instruments and policies insofar as the ones existing are traditionally conceived and targeted to a much too wide territorial aggregation level to be able to cope with each territorial unit's weaknesses and specificities and, therefore, compromising its efficiency and effectiveness.

These results also suggest some public management measures regarding such aspects as land use and organization and public budgeting which are essential in terms of development if a larger territorial cohesion is to be attained. We refer naturally to such measures likely to increase the literacy level, to fight the depopulation of the hinterland as well as increasing entrepreneurial attractiveness, namely by investing in schools, in the continuous training of teaching agents and in other communication infra-structures. This may be achieved with recourse to tax incentives that may help high skilled human resources settle all over the country and attract private investment in a diversified entrepreneurial tissue.

In short, centralized management of regional develop ment policies has been one of the main obstacles to a more equal distribution of resources that might lead to equal opportunities in territorial development. It is important to point out that this study was carried out through calculating indicators that referred to the total area of Mainland Portugal. Recalcu lating these values based on a smaller territorial unit like NUT II and NUT III will certainly be a useful topic to pursue in further research. 


\section{ANNEX I}

Table I.1. Per cent distribution of the Concelhos according to SEDI levels

\begin{tabular}{|c|c|c|c|}
\hline SEDI & Concelhos & No & $\%$ \\
\hline$[0-0,25[$ & Mértola; Vinhais. & 2 & 0,7 \\
\hline$[0,25-0,3[$ & $\begin{array}{l}\text { Aguiar da Beira; Alcoutim; Barrancos; Boticas; Carrazeda de Ansiães; Freixo de Espada à Cinta; } \\
\text { Gavião; Idanha-a-Nova; Montalegre; Oleiros; Pampilhosa da Serra;Penamacor; Ribeira de Pena; } \\
\text { Torre de Moncorvo; Valpaços; Vimioso. }\end{array}$ & 16 & 5,8 \\
\hline$[0,3-0,35[$ & $\begin{array}{l}\text { Alandroal; Alfầndega da Fé; Alijó; Aljustrel; Almeida; Almodôvar; Arcos de Valdevez; Armamar; } \\
\text { Avis; Castanheira de Pêra; Castro Daire; Coruche; Cuba; Ferreira do Alentejo; Figueira de Castelo } \\
\text { Rodrigo; Fornos de Algodres; Fronteira; Melgaço; Mesão Frio; Mogadouro; Monção; Monchique; } \\
\text { Mondim de Basto; Mora; Murça; Odemira; Ourique; Paredes de Coura;Pedrógão Grande; Penedono; } \\
\text { Portel; Proença-a-Nova; Resende; Sabrosa; Sabugal; São João da Pesqueira; Sernancelhe; Serpa; } \\
\text { Tabuaço;T arouca; Terras de Bouro; Trancoso; Vila Flor; Vila Nova de Foz Côa; Vila Pouca de } \\
\text { Aguiar; Vila Velha de Ródão. }\end{array}$ & 46 & 16,5 \\
\hline$[0,35-0,4[$ & $\begin{array}{l}\text { Alcácer do Sal; Aljezur; Alpiarça; Alter do Chão; Alvaiázere; Alvito; Arganil; Arraiolos; Arronches; } \\
\text { Baião; Cadaval; Castro Marim; Celorico da Beira; Celorico de Basto; Chamusca; Cinfães; Crato; } \\
\text { Ferreira do Zêzere; Figueiró dos Vinhos; Góis; Gouveia; Grândola; Mação; Macedo de Cavaleiros; } \\
\text { Marvão; Meda; Miranda do Douro; Mirandela; Moimenta da Beira; Monforte; Montemor-o-Velho; } \\
\text { Mortágua; Moura; Mourão; Nisa; Penalva do Castelo;Pinhel; Ponte da Barca;Ponte de Sor; } \\
\text { Redondo; Salvaterra de Magos; Santa Comba Dão; Santa Marta de Penaguião; São Pedro do Sul; } \\
\text { Sardoal; Sátão; Seia; Sertã; Soure; Sousel; Tondela; Vidigueira; Vieira do Minho; Vila de Rei; Vila } \\
\text { Nova de Paiva; Vouzela. }\end{array}$ & 56 & 20,1 \\
\hline$[0,4-0,45[$ & $\begin{array}{l}\text { Abrantes; Almeirim; Amarante; Amares; Ansião; Arouca; Belmonte; Bombarral; Borba; Bragança; } \\
\text { Cabeceiras de Bast o; Caminha; Campo Maior; Cantanhede; Carregal do Sal; Castelo de Paiva; } \\
\text { Castelo de Vide; Castro Verde; Chaves; Elvas; Estremoz; Fundão; Golegã; Lamego; Lourinhã; } \\
\text { Mangualde; Manteigas; Mira; Montemor-o-Novo; Murtosa; Nazaré; Nelas; Óbidos; Oliveira de } \\
\text { Frades; Oliveira do Hospital; Penacova;Penela;Peniche; Peso da Régua; Pombal; Ponte de Lima; } \\
\text { Póvoa de Lanhoso; Reguengos de Monsaraz; Santiago do Cacém; Sever do Vouga; Tábua; Tavira; } \\
\text { Tomar; Vale de Cambra; Valença; Vila do Bispo; Vila Nova da Barquinha; Vila Nova de Cerveira; } \\
\text { Vila Nova de Poiares; Vila Verde. }\end{array}$ & 55 & 19,8 \\
\hline$[0,45-0,5[$ & $\begin{array}{c}\text { Albergaria-a-Velha; Alcanena; Alcobaça; Anadia; Arruda dos Vinhos; Azambuja; Barcelos; } \\
\text { Barreiro; Beja; Cartaxo; Castelo Branco; Constância; Covilhã; Espinho; Estarreja; Fafe; Figueira da } \\
\text { Foz; Marco de Canaveses; Mealhada; Miranda do Corvo; Moita; Montijo; Olhão; Oliveira de } \\
\text { Azeméis; Oliveira do Bairro; Ourém;Penafiel; Portalegre;Porto de Mós; Rio Maior; Santarém; Santo } \\
\text { Tirso; São Brás de Alportel; Silves; Sobral de Monte Agraço; Torres Novas; Torres Vedras; Vagos; } \\
\text { Vendas Novas; Viana do Alentejo; Viana do Castelo; Vila Real; Vila Real de Santo António; Vila } \\
\text { Viçosa. }\end{array}$ & 44 & 15,8 \\
\hline$[0,5-0,55[$ & $\begin{array}{l}\text { Águeda; Alcochete; Alenquer; Almada; Amadora; Batalha; Benavente; Caldas da Rainha; } \\
\text { Condeixa-a-Nova; Esposende; Évora; Felgueiras; Gondomar; Guarda; Guimarães; Ílhavo; Lagoa; } \\
\text { Lagos; Leiria; Loulé; Loures; Lousã; Lousada; Marinha Grande; Matosinhos; Ovar;Paços de } \\
\text { Ferreira;Palmela;Paredes; Póvoa do Varzim; Santa Maria da Feira; Sesimbra; Setúbal; Sines; } \\
\text { Valongo; Vila do Conde; Vila Nova de Famalicão; Viseu. }\end{array}$ & 38 & 13,7 \\
\hline$[0,55-0,6[$ & $\begin{array}{l}\text { Aveiro; Braga; Coimbra; Entroncamento; Faro; Mafra; Maia; Odivelas; Port imão; Porto; São João da } \\
\text { Madeira; Seixal; Trofa; Vila Franca de Xira; Vila Nova de Gaia; Vizela. }\end{array}$ & 16 & 5,8 \\
\hline$[0,6-0,7]$ & Albufeira; Cascais; Lisboa; Oeiras; Sintra. & 5 & 1,8 \\
\hline & Total & 278 & 100 \\
\hline
\end{tabular}




\section{ANNEX II - Cluster Analysis (K-means)}

II.1. Cluster Membership

\begin{tabular}{|c|c|c|c|c|c|c|c|c|}
\hline $\mathrm{N}$ & Concelho & Cluster & $\mathrm{N}$ & Concelho & Cluster & $\mathrm{N}$ & Concelho & Cluster \\
\hline 2 & Caminha & 1 & 122 & Ansião & 1 & 183 & Tomar & 1 \\
\hline 7 & Ponte de Lima & 1 & 124 & Figueiró dos Vinhos & 1 & 184 & Torres Novas & 1 \\
\hline 8 & Valença & 1 & 127 & Carregal do Sal & 1 & 185 & Vila Nova da Barquinha & 1 \\
\hline 10 & Vila Nova de Cerveira & 1 & 129 & Mangualde & 1 & 207 & Grândola & 1 \\
\hline 20 & Vieira do Minho & 1 & 130 & Mortágua & 1 & 208 & Santiago do Cacém & 1 \\
\hline 35 & Cabeceiras de Basto & 1 & 131 & Nelas & 1 & 214 & Campo Maior & 1 \\
\hline 36 & Celorico de Basto & 1 & 132 & Oliveira de Frades & 1 & 215 & Castelo de Vide & 1 \\
\hline 38 & Baião & 1 & 134 & Santa CombaDão & 1 & 217 & Elvas & 1 \\
\hline 47 & Cinfães & 1 & 135 & São Pedro do Sul & 1 & 223 & Ponte de Sor & 1 \\
\hline 49 & Arouca & 1 & 137 & Tondela & 1 & 224 & Portalegre & 1 \\
\hline 53 & Vale de Cambra & 1 & 140 & Vouzela & 1 & 226 & Arraiolos & 1 \\
\hline 61 & Peso da Régua & 1 & 148 & Seia & 1 & 227 & Borba & 1 \\
\hline 66 & Lamego & 1 & 150 & Celorico da Beira & 1 & 228 & Estremoz & 1 \\
\hline 74 & Bragança & 1 & 153 & Manteigas & 1 & 230 & Montemor-o-Novo & 1 \\
\hline 77 & Mirandela & 1 & 155 & Pinhel & 1 & 231 & Mourão & 1 \\
\hline 82 & Chaves & 1 & 158 & Castelo Branco & 1 & 233 & Redondo & 1 \\
\hline 94 & Murtosa & 1 & 162 & Belmonte & 1 & 234 & Reguengos de Monsaraz & 1 \\
\hline 97 & Sever do Vouga & 1 & 163 & Covilhã & 1 & 236 & Viana do Alentejo & 1 \\
\hline 99 & Cantanhede & 1 & 164 & Fundão & 1 & 237 & Vila Viçosa & 1 \\
\hline 102 & Figueira da Foz & 1 & 166 & Bombarral & 1 & 244 & Castro Verde & 1 \\
\hline 103 & Mira & 1 & 168 & Nazaré & 1 & 252 & Azambuja & 1 \\
\hline 104 & Mont emor-o-Velho & 1 & 169 & Óbidos & 1 & 253 & Almeirim & 1 \\
\hline 105 & Penacova & 1 & 170 & Peniche & 1 & 254 & Alpiarça & 1 \\
\hline 106 & Soure & 1 & 173 & Cadaval & 1 & 259 & Golegã & 1 \\
\hline 110 & Pombal & 1 & 174 & Lourinhã & 1 & 261 & Salvaterra de Magos & 1 \\
\hline 112 & Arganil & 1 & 177 & Abrantes & 1 & 266 & Castro Marim & 1 \\
\hline 116 & Oliveira do Hospital & 1 & 178 & Alcanena & 1 & 275 & Silves & 1 \\
\hline 118 & Penela & 1 & 179 & Constância & 1 & 276 & Tavira & 1 \\
\hline 119 & Tábua & 1 & 181 & Ferreira do Zêzere & 1 & 277 & Vila do Bispo & 1 \\
\hline 120 & Vila Nova de Poiares & 1 & 182 & Sardoal & 1 & & Number of cases & 89 \\
\hline
\end{tabular}




\begin{tabular}{|c|c|c|c|c|c|c|c|c|}
\hline $\mathrm{N}$ & Concelho & Cluster & $\mathrm{N}$ & Concelho & Cluster & $\mathrm{N}$ & Concelho & Cluster \\
\hline 9 & Viana do Castelo & 2 & 40 & Lousada & 2 & 111 & Porto de Mós & 2 \\
\hline 11 & Amares & 2 & 41 & Marco de Canaveses & 2 & 114 & Lousã & 2 \\
\hline 12 & Barcelos & 2 & 42 & Paços de Ferreira & 2 & 115 & Miranda do Corvo & 2 \\
\hline 14 & Esposende & 2 & 43 & Paredes & 2 & 165 & Alcobaça & 2 \\
\hline 16 & Vila Verde & 2 & 44 & Penafiel & 2 & 171 & Alenquer & 2 \\
\hline 17 & Fafe & 2 & 50 & Santa Maria da Feira & 2 & 172 & Arruda dos Vinhos & 2 \\
\hline 18 & Guimarães & 2 & 51 & Oliveira de Azeméis & 2 & 175 & Sobral de Monte Agraço & 2 \\
\hline 19 & Póvoa de Lanhoso & 2 & 87 & Águeda & 2 & 176 & Torres Vedras & 2 \\
\hline 21 & Vila Nova de Famalicão & 2 & 88 & Albergaria-a-Velha & 2 & 186 & Ourém & 2 \\
\hline 22 & Vizela & 2 & 89 & Anadia & 2 & 194 & Odivelas & 2 \\
\hline 23 & Santo Tirso & 2 & 91 & Estarreja & 2 & 199 & Moita & 2 \\
\hline 24 & Trofa & 2 & 93 & Mealhada & 2 & 235 & VendasNovas & 2 \\
\hline 26 & Gondomar & 2 & 95 & Oliveira do Bairro & 2 & 256 & Cartaxo & 2 \\
\hline 32 & Vila do Conde & 2 & 96 & Ovar & 2 & 260 & Rio Maior & 2 \\
\hline 34 & Castelo dePaiva & 2 & 98 & Vagos & 2 & 272 & Olhão & 2 \\
\hline 37 & Amarante & 2 & 107 & Batalha & 2 & 274 & São Brás de Alportel & 2 \\
\hline 39 & Felgueiras & 2 & 109 & Marinha Grande & 2 & & Number of cases & 50 \\
\hline
\end{tabular}

\begin{tabular}{|c|c|c|c|c|c|c|c|c|}
\hline $\mathrm{N}$ & Concelho & Cluster & $\mathrm{N}$ & Concelho & Cluster & $\mathrm{N}$ & Concelho & Cluster \\
\hline 1 & Arcos de Valdevez & 3 & 81 & Boticas & 3 & 206 & Alcácer do Sal & 3 \\
\hline 3 & Melgaço & 3 & 83 & Montalegre & 3 & 210 & Mora & 3 \\
\hline 4 & Monção & 3 & 84 & Murça & 3 & 211 & Alter do Chão & 3 \\
\hline 5 & Paredes de Coura & 3 & 85 & Valpaços & 3 & 212 & Arronches & 3 \\
\hline 6 & Ponte da Barca & 3 & 86 & Vila Pouca de Aguiar & 3 & 213 & Avis & 3 \\
\hline 15 & Terras de Bouro & 3 & 113 & Góis & 3 & 216 & Crato & 3 \\
\hline 45 & Mondim de Basto & 3 & 117 & Pampilhosa da Serra & 3 & 218 & Fronteira & 3 \\
\hline 46 & Ribeira de Pena & 3 & 121 & Alvaiázere & 3 & 219 & Gavião & 3 \\
\hline 48 & Resende & 3 & 123 & Castanheira de Pêra & 3 & 220 & Marvão & 3 \\
\hline 54 & Carrazeda de Ansiães & 3 & 125 & Pedrógão Grande & 3 & 221 & Monforte & 3 \\
\hline 55 & Freixo de Espada à Cinta & 3 & 126 & Aguiar da Beira & 3 & 222 & Nisa & 3 \\
\hline 56 & Torre de Moncorvo & 3 & 128 & Castro Daire & 3 & 225 & Alandroal & 3 \\
\hline 57 & Vila Flor & 3 & 133 & Penalva do Castelo & 3 & 232 & Portel & 3 \\
\hline 58 & Vila Nova de Foz Côa & 3 & 136 & Sátão & 3 & 238 & Sousel & 3 \\
\hline 59 & Alijó & 3 & 138 & Vila Nova de Paiva & 3 & 239 & Aljustrel & 3 \\
\hline 60 & MesãoFrio & 3 & 141 & Oleiros & 3 & 240 & Almodôvar & 3 \\
\hline 62 & Sabrosa & 3 & 142 & Proença-a-Nova & 3 & 241 & Alvito & 3 \\
\hline 63 & Santa Marta dePenaguião & 3 & 143 & Sertã & 3 & 242 & Barrancos & 3 \\
\hline 65 & Armamar & 3 & 144 & Vila de Rei & 3 & 245 & Cuba & 3 \\
\hline 67 & Moimenta da Beira & 3 & 145 & Mação & 3 & 246 & Ferreira do Alentejo & 3 \\
\hline 68 & Penedono & 3 & 146 & Fornos de Algodres & 3 & 247 & Mértola & 3 \\
\hline 69 & São João da Pesqueira & 3 & 147 & Gouveia & 3 & 248 & Moura & 3 \\
\hline 70 & Sernancelhe & 3 & 149 & Almeida & 3 & 249 & Ourique & 3 \\
\hline 71 & Tabuaço & 3 & 151 & Figueira de Castelo Rodrigo & 3 & 250 & Serpa & 3 \\
\hline 72 & Tarouca & 3 & 154 & Meda & 3 & 251 & Vidigueira & 3 \\
\hline 73 & Alfândega da Fé & 3 & 156 & Sabugal & 3 & 257 & Chamusca & 3 \\
\hline 75 & Macedo de Cavaleiros & 3 & 157 & Trancoso & 3 & 258 & Coruche & 3 \\
\hline 76 & Miranda do Douro & 3 & 159 & Idanha-a-Nova & 3 & 264 & Alcoutim & 3 \\
\hline 78 & Mogadouro & 3 & 160 & Penamacor & 3 & 265 & Aljezur & 3 \\
\hline 79 & Vimioso & 3 & 161 & Vila Velha de Ródão & 3 & 271 & Monchique & 3 \\
\hline 80 & Vinhais & 3 & 205 & Odemira & 3 & & Number of cases & 92 \\
\hline
\end{tabular}




\begin{tabular}{|lcc|ccc|lcc|}
\hline N & Concelho & Cluster & N & Concelho & Cluster & N & Concelho & Cluster \\
\hline 13 & Braga & 5 & 152 & Guarda & 5 & 202 & Seixal & 5 \\
25 & Espinho & 5 & 167 & Caldas da Rainha & 5 & 203 & Sesimbra & 5 \\
27 & Maia & 5 & 180 & Entroncamento & 5 & 204 & Setúbal & 5 \\
28 & Matosinhos & 5 & 187 & Cascais & 5 & 209 & Sines & 5 \\
30 & Póvoa de Varzim & 5 & 189 & Loures & 5 & 229 & Évora & 5 \\
31 & Valongo & 5 & 190 & Oeiras & 5 & 243 & Beja & 5 \\
33 & Vila Nova de Gaia & 5 & 191 & Sintra & 5 & 255 & Benavente & 5 \\
52 & São João da Madeira & 5 & 192 & Vila Franca de Xira & 5 & 262 & Santarém & 5 \\
64 & Vila Real & 5 & 193 & Amadora & 5 & 263 & Albufeira & 5 \\
90 & Aveiro & 5 & 195 & Mafra & 5 & 267 & Faro & 5 \\
92 & Ílhavo & 5 & 196 & Alcochete & 5 & 268 & Lagoa & 5 \\
100 & Coimbra & 5 & 197 & Almada & 5 & 269 & Lagos & 5 \\
101 & Condeixa-a-Nova & 5 & 198 & Barreiro & 5 & 270 & Loulé & 5 \\
108 & Leiria & 5 & 200 & Montijo & 5 & 273 & Portimão & 5 \\
139 & Viseu & 5 & 201 & Palmela & 5 & 278 & Vila Real de Santo António & 5 \\
\cline { 6 - 8 } & & & & & Number of cases & 45 \\
\hline
\end{tabular}

II.2. Number of Cases in each Cluster

\begin{tabular}{|c|c|c|}
\hline \multirow{5}{*}{ Cluster } & 1 & 89 \\
\hline & 2 & 50 \\
\hline & 3 & 92 \\
\hline & 4 & 2 \\
\hline & 5 & 45 \\
\hline \multicolumn{2}{|c|}{ Valid } & 278 \\
\hline \multicolumn{2}{|c|}{ Missing } & 0 \\
\hline
\end{tabular}

II.3. Final Cluster Centres

\begin{tabular}{|c|c|c|c|c|c|}
\hline & \multicolumn{5}{|c|}{ Cluster } \\
\cline { 2 - 6 } & 1 & 2 & 3 & 4 &, 074 \\
\hline I1 &, 257 &, 431 &, 134 &, 624 &, 498 \\
I2 &, 590 &, 813 &, 421 &, 207 &, 806 \\
I3 &, 790 &, 801 &, 788 &, 600 &, 722 \\
I4 &, 511 &, 657 &, 387 &, 940 &, 864 \\
I5 &, 657 &, 821 &, 452 &, 848 &, 389 \\
I6 &, 151 &, 166 &, 083 &, 761 &, 817 \\
I7 &, 662 &, 805 &, 488 &, 679 &, 771 \\
I8 &, 782 &, 853 &, 687 &, 997 &, 935 \\
I9 &, 786 &, 915 &, 577 &, 030 &, 059 \\
I10 &, 028 &, 100 &, 014 &, 654 &, 223 \\
I11 &, 118 &, 135 &, 089 &, 832 &, 273 \\
I12 &, 109 &, 124 &, 058 &, 647 &, 055 \\
I13 &, 009 &, 029 &, 003 &, 677 &, 200 \\
I14 &, 159 &, 113 &, 139 &, 654 &, 684 \\
I15 &, 605 &, 595 &, 594 & & \\
\hline
\end{tabular}

II.4. Distances between Final Cluster Centres

\begin{tabular}{|c|c|c|c|c|c|}
\hline Cluster & 1 & 2 & 3 & 4 & 5 \\
\hline 1 & &, 423 &, 439 & 1,582 &, 590 \\
2 &, 423 & &, 846 & 1,587 &, 340 \\
3 &, 439 &, 846 & & 1,769 &, 993 \\
4 & 1,582 & 1,587 & 1,769 & & 1,378 \\
5 &, 590 &, 340 &, 993 & 1,378 & \\
\hline
\end{tabular}


II.5. ANOVA

\begin{tabular}{|c|c|c|c|c|c|c|}
\hline & \multicolumn{2}{|c|}{ Cluster } & \multicolumn{2}{|c|}{ Error } & \multirow{2}{*}{ S } & Sig. \\
\cline { 2 - 6 } & Mean Square & $\mathrm{df}$ & Mean Square & $\mathrm{df}$ & &, 000 \\
I1 & 1,338 & 4 &, 009 & 273 & 150,450 &, 000 \\
I2 & 1,816 & 4 &, 013 & 273 & 140,640 &, 000 \\
I3 &, 174 & 4 &, 001 & 273 & 173,175 &, 000 \\
I4 & 1,098 & 4 &, 023 & 273 & 48,115 &, 000 \\
I5 & 1,825 & 4 &, 012 & 273 & 152,984 &, 000 \\
I6 &, 949 & 4 &, 007 & 273 & 132,713 &, 000 \\
I7 & 1,223 & 4 &, 016 & 273 & 78,724 &, 000 \\
I8 &, 247 & 4 &, 013 & 273 & 18,955 &, 000 \\
I9 & 1,455 & 4 &, 014 & 273 & 107,533 &, 000 \\
I10 &, 067 & 4 &, 006 & 273 & 10,504 &, 000 \\
I11 &, 277 & 4 &, 007 & 273 & 36,961 &, 000 \\
I12 &, 606 & 4 &, 003 & 273 & 206,064 &, 000 \\
I13 &, 220 & 4 &, 001 & 273 & 158,075 &, 000 \\
I14 &, 188 & 4 &, 005 & 273 & 39,351 &, 000 \\
I15 &, 071 & 4 &, 004 & 273 & 18,991 & \\
\hline
\end{tabular}

II.6. One-way

\begin{tabular}{|c|c|c|c|c|c|c|c|c|c|}
\hline \multicolumn{10}{|c|}{ Descript ive } \\
\hline & & \multirow[t]{2}{*}{$\mathrm{N}$} & \multirow[t]{2}{*}{ Mean } & \multirow{2}{*}{$\begin{array}{c}\text { Std. } \\
\text { Deviation }\end{array}$} & \multirow{2}{*}{$\begin{array}{l}\text { Std. } \\
\text { Error }\end{array}$} & \multicolumn{2}{|c|}{$95 \%$ Conf. Int. Mean } & \multirow[t]{2}{*}{ Minimum } & \multirow[t]{2}{*}{ Maximum } \\
\hline & & & & & & Lower Bound & Upper Bound & & \\
\hline \multirow[t]{6}{*}{ I1 } & 1 & 89 & 257 & ,071 & ,008 & 242 & 272 & ,077 & 484 \\
\hline & 2 & 50 &, 431 &, 082 &, 012 & ,408 & 454 & 316 &, 752 \\
\hline & 3 & 92 & 134 & .068 & 007 & .120 & 148 & .000 & 354 \\
\hline & 4 & 2 &, 074 & ,019 &, 014 &,- 099 & 247 &, 060 & ,088 \\
\hline & 5 & 45 & ,498 & , 167 &, 025 & ,448 & ,548 &, 161 & 1,000 \\
\hline & Total & 278 &, 285 &, 168 &, 010 & 266 &, 305 &, 000 & 1,000 \\
\hline \multirow[t]{6}{*}{$\mathrm{I} 2$} & 1 & 89 &, 590 &, 082 &, 009 & 573 & 607 &, 372 & ,779 \\
\hline & 2 & 50 &, 813 & , 105 &, 015 & ,783 & ,843 & ,558 & 1,000 \\
\hline & 3 & 92 & ,421 & , 150 &, 016 & ,390 & ,452 &, 000 & ,720 \\
\hline & 4 & 2 &, 624 &, 033 &, 024 & 324 & ,923 & ,600 & ,647 \\
\hline & 5 & 45 &, 814 & 087 &, 013 & ,788 & 840 & 629 & ,983 \\
\hline & Total & 278 & ,611 & , 197 &, 012 & ,587 & ,634 &, 000 & 1,000 \\
\hline \multirow[t]{6}{*}{$\mathrm{I} 3$} & 1 & 89 & ,790 &, 006 & ,001 & ,789 & ,791 & ,773 & ,806 \\
\hline & 2 & 50 & 801 & 018 & .003 & .796 & .806 & .766 & 864 \\
\hline & 3 & 92 & ,788 & ,002 &, 000 & ,788 & ,789 & ,782 & 794 \\
\hline & 4 & 2 & ,207 & ,292 & ,207 & $-2,418$ & 2,832 &, 000 & ,413 \\
\hline & 5 & 45 &, 806 & 062 &, 009 & ,787 &, 825 & 654 & 1,000 \\
\hline & Total & 278 &, 790 &, 059 &, 004 &, 783 &, 797 &, 000 & 1,000 \\
\hline \multirow[t]{6}{*}{ I4 } & 1 & 89 &, 511 & , 146 &, 015 & ,481 & 542 & 240 & 1,000 \\
\hline & 2 & 50 & ,657 & , 120 &, 017 & ,623 & 691 & ,395 & ,892 \\
\hline & 3 & 92 &, 387 & , 177 &, 018 & ,350 & ,424 & ,000 & ,801 \\
\hline & 4 & 2 & ,600 & ,156 &, 110 &,- 800 & 2,000 & ,490 &, 710 \\
\hline & 5 & 45 & ,722 & ,134 &, 020 & 682 & ,762 & ,414 & ,997 \\
\hline & Total & 278 &, 531 & ,196 &, 012 &, 508 &, 554 &, 000 & 1,000 \\
\hline \multirow[t]{6}{*}{ I5 } & 1 & 89 & ,657 &, 111 & ,012 &, 634 & 681 & ,401 & ,880 \\
\hline & 2 & 50 &, 821 &, 070 &, 010 & ,802 &, 841 & ,673 & 951 \\
\hline & 3 & 92 & ,452 & ,133 &, 014 & ,425 & ,480 & ,000 & 669 \\
\hline & 4 & 2 & ,940 &, 030 &, 021 & ,672 & 1,209 & 919 & 961 \\
\hline & 5 & 45 &, 864 & 087 &, 013 & ,838 &, 890 & ,676 & 1,000 \\
\hline & Total & 278 & ,654 & , 195 &, 012 & 631 & 677 & 000 & 1,000 \\
\hline \multirow[t]{6}{*}{ I6 } & 1 & 89 & ,151 & 073 & ,008 &, 136 & 166 & 019 & ,418 \\
\hline & 2 & 50 &, 166 &, 070 &, 010 &, 146 & ,186 &, 045 &, 346 \\
\hline & 3 & 92 &, 083 & ,038 &, 004 &, 075 & ,091 & ,003 & ,199 \\
\hline & 4 & 2 &, 848 & ,103 &, 073 &,- 073 & 1,770 & ,776 & 921 \\
\hline & 5 & 45 & ,389 &, 158 &, 024 & 341 & 437 & 187 & 1,000 \\
\hline & Total & 278 &, 175 &, 144 &, 009 & 158 & 192 &, 003 & 1,000 \\
\hline \multirow[t]{6}{*}{ I7 } & 1 & 89 & ,662 &, 112 &, 012 & ,638 & ,686 & ,325 &, 888 \\
\hline & 2 & 50 & ,805 & , 106 &, 015 &, 775 & ,835 & ,564 & 1,000 \\
\hline & 3 & 92 & ,488 & , 157 &, 016 & ,455 &, 521 & ,000 & ,770 \\
\hline & 4 & 2 &, 761 & 100 &, 071 &,- 135 & 1,658 & ,691 &, 832 \\
\hline & 5 & 45 &, 817 & 085 &, 013 & ,791 & 842 &, 575 & 990 \\
\hline & Total & 278 &, 656 & , 182 &, 011 & 634 & ,677 &, 000 & 1,000 \\
\hline \multirow[t]{2}{*}{ I8 } & 1 & 89 &, 782 &, 092 &, 010 &, 763 & ,802 &, 520 & ,959 \\
\hline & 2 & 50 &, 853 &, 078 &, 011 &, 831 & 875 &, 582 & 1,000 \\
\hline
\end{tabular}




\begin{tabular}{|c|c|c|c|c|c|c|c|c|c|}
\hline & 3 & 92 & .687 & 158 & .016 & .654 & .719 & 000 & 959 \\
\hline & 4 & 2 & 679 &, 101 &, 071 &,- 229 & 1,586 & 607 & 750 \\
\hline & 5 & 45 &, 771 & 073 &, 011 & ,749 & ,793 & ,607 & ,939 \\
\hline & Total & 278 &, 761 &, 128 &, 008 &, 746 & ,776 &, 000 & 1,000 \\
\hline I9 & 1 & 89 & ,786 & ,101 & ,011 & ,765 & ,807, & ,550 & ,964 \\
\hline & 2 & 50 & ,915 & ,058 & ,008 & 899, & 932 & ,750 & ,999 \\
\hline & 3 & 92 & ,577, & , 165 & ,017 & 543, & 612, &, 000 & ,952 \\
\hline & 4 & 2 & ,997 & ,002 & ,001 & 983 & 1,012 & ,996 & ,999 \\
\hline & 5 & 45 & ,935 &, 057 &, 008 & ,918 & ,953 &, 812 & 1,000 \\
\hline & Total & 278 & ,766 & , 185 &, 011 & ,744 & ,788 &, 000 & 1,000 \\
\hline $\mathrm{I} 10$ & 1 & 89 & ,028 & ,008 & ,001 & ,027 & ,030 & ,010 & ,059 \\
\hline & 2 & 50 & , 100 & ,187 &, 026 & ,046 & ,153 &, 025 & 1,000 \\
\hline & 3 & 92 & ,014 &, 007 & 001 & ,013 & ,016 &, 000 &, 031 \\
\hline & 4 & 2 & ,030 &, 007 & ,005 &,- 029 & 089, &, 025 &, 034 \\
\hline & 5 & 45 & 059 &, 017 &, 003 & ,054 & ,065 &, 028 &, 106 \\
\hline & Total & 278 &, 042 &, 085 &, 005 &, 031 &, 052 &, 000 & 1,000 \\
\hline I11 & 1 & 89 & ,118 & ,081 & ,009 & , 101 & , 135 &, 000 &, 746 \\
\hline & 2 & 50 & , 135 &, 048 & 007 &, 121 & , 148 &, 050 & ,237 \\
\hline & 3 & 92 & 089 &, 069 &, 007 & ,074 & ,103 &, 008 &, 503 \\
\hline & 4 & 2 & 654 & 204 &, 145 & $-1,184$ & 2,491 & ,509 &, 798 \\
\hline & 5 & 45 & 223 &, 141 & 021 & 181 & ,265 & 105 & 1,000 \\
\hline & Total & 278 &, 132 &, 107 &, 006 & ,119 &, 145 &, 000 & 1,000 \\
\hline $\mathrm{I} 12$ & 1 & 89 & , 109 &, 048 & ,005 & ,099 & ,119 &, 000 & 242 \\
\hline & 2 & 50 & ,124 &, 047 & ,007 &, 110 & ,137 &, 041 & 287 \\
\hline & 3 & 92 & 058 &, 027 & ,003 &, 052 & 063 &, 001 &, 147 \\
\hline & 4 & 2 & ,832 & ,238 & ,168 & $-1,306$ & 2,969 & ,664 & 1,000 \\
\hline & 5 & 45 & ,273 & ,091 & ,014 & 246, & ,300 & 145 & ,589 \\
\hline & Total & 278 &, 126 & ,108 &, 006 & ,114 & ,139 &, 000 & 1,000 \\
\hline $\mathrm{I} 13$ & 1 & 89 & ,009 & ,007 & ,001 & ,008 & ,011 & ,001 & ,039 \\
\hline & 2 & 50 & 029 &, 023 &, 003 &, 022 & ,035 & ,004 & ,094 \\
\hline & 3 & 92 & 003 &, 002 &, 000 & ,002 & 003 &, 000 &, 013 \\
\hline & 4 & 2 & 647 & ,499 &, 353 & $-3,839$ & 5,133 & 294 & 1,000 \\
\hline & 5 & 45 & 055 &, 048 & 007 & ,041 & ,070 &, 006 & ,215 \\
\hline & Total & 278 &, 023 &, 068 &, 004 &, 015 &, 031 &, 000 & 1,000 \\
\hline I14 & 1 & 89 & 159 &, 058 &, 006 & , 147 & ,171 &, 072 & 376 \\
\hline & 2 & 50 &, 113 & ,039 & 006 & , 101 &, 124 &, 058 & 239 \\
\hline & 3 & 92 & ,139 & ,059 & 006 & , 127 & , 151 &, 032 & ,416 \\
\hline & 4 & 2 & 677, & 035 &, 025 & 361 & 994, & ,652 & ,702 \\
\hline & 5 & 45 & 200 & ,118 & ,018 & 164, & ,235 & ,078 & ,765 \\
\hline & Total & 278 &, 154 &, 086 &, 005 &, 144 &, 164 &, 032 &, 765 \\
\hline I15 & 1 & 89 & 605 &, 068 &, 007 &, 590 & ,619 &, 354 &, 742 \\
\hline & 2 & 50 &, 595 &, 068 &, 010 &, 576 & 615 &, 474 &, 719 \\
\hline & 3 & 92 & ,594 &, 057 & 006 & ,583 & 606 &, 433 &, 704 \\
\hline & 4 & 2 & 654 &, 007 & 005 & ,594 & ,713 & 649 & ,658 \\
\hline & 5 & 45 & 684 &, 044 &, 007 & 670 & 697 &, 599 &, 787 \\
\hline & Total & 278 &, 613 &, 068 &, 004 &, 605 &, 621 &, 354 &, 787 \\
\hline
\end{tabular}

\section{ACKNOWLEDGEMENTS}

The authors wish to thank Dr. Luís Rodrigues for this contribution to calculating SEDI.

\section{REFERENCES}

[1] N. Baster, Measuring Development - The Role and Adequacy of Development Indicators, London: Frank Cass and Company Limited, 1972.

[2] D. Seers, "Os indicadores de desenvolvimento: o que estamos a tentar medir?", Análise Social, vol. XV, 19, 1972.

[3] PNUD, Relatório do Desenvolvimento Humano 1997 - 2003, Lisboa: Trinova Editora, 2006.
[4] F. Diniz, An Essay on Definitions of Typologies for Less favoured areas - Two Portuguese Regions: Alto Trá-os-Montes and Douro, Electronic version of accepted papers do XIII World Congress of IEA, Centro Cultural de Belém, September 9-13, Lisboa, 2002.

[5] OECD, OECD core set of indicators for environmental performance reviews, Paris: OEDC Environment Monographs No. 83, 1993.

[6] INE, Recenseamento Geral da População e da Habitação Censos 2001, Lisboa: INE, 2001.

[7] INE, Anuário Estatístico 2001, Lisboa: INE, 2002.

[8] INE, Anuário Estatístico 2002, Lisboa: INE, 2003.

[9] INE, Estudo sobre o Poder de Compra Concelhio - 2004, Número VI, Lisboa: INE, 2005.

[10] P. Ramos, "Estimativas do PIB per capita para os Concelhos 
do Continente Português", Revista de Estatística, 30 Quadrimestre de 1998, V.3, pp. 29-49, 1998.

[11] João Maroco, Análise Estatística com utilização do SPSS, $2^{\mathrm{a}}$ Edição, Lisboa: Edições Sílabo, 2003.

[12] Maria Helena Pestana and João Nunes Gageiro, Análise de dados para as Ciências Sociais. A complementaridade do SPSS, $3^{\text {a }}$ Edição Revista e aumentada, Lisboa: Edições Sílabo, 2003.

[13] PNUD, Relatório do Desenvolvimento Humano 1990 - 1993. Nova Iorque: Oxford University Press, 1993.
[14] PNUD, Relatório do Desenvolvimento Humano 1994 - 1996, Lisboa: Tricontinental Editora, 1996.

[15] Elisabeth Reis, "Análise de Clusters: Um Método de Classificação sem Preconceitos", Temas em Métodos Quantitativos para a Gestão, ${ }^{\circ}$ 6, Lisboa: GIESTA, ISCTE, 1993.

[16] Comissão das Comunidades, EDEC - 1999 - Para um desenvolvimento equilibrado e sustentável do territorial da União Europeia, Maio, Potsdam, 1999.

[17] César P. Lopez, MétodosEstadísticosAvanzados com SPSS, Madrid: Thomson, 2005.

\footnotetext{
i NUTS IV.

ii Based on a Friend's and Rapport's work (1979), the OECD [5] developed a model called Pressure - status quo - Answer (PSA) according to a causality concept which postulates that human activities exert some sort of pressure which qualitatively change the economic, social and environmental systems' status quo, therefore creating the need for an ad equate answer through different policies and instruments.

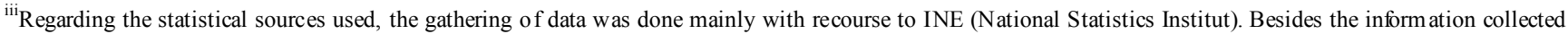
from Census 2001 [6] and Statistics Year Book 2001 and 2002 [7, 8], other publications were looked up in the Internet at www.ine.pt, such as Estudo do Poder de CompraConcelhio 2004 (Study on Purchasing Power) [9], concerning indicator I12 - Purchasing Power. On the other hand, indicator I11 - per head GNP was calculat ed with recourse to Pedro Nogueira Ramos's Estimates on per head GNP in Mainland Portugal's Concelhos [10].

${ }^{i v}$ The Entrepreneurial Index per Concelho is the result of aggregating four indicators with equal weighting, namely: a) Business firms bas ed on the region; b) Partnerships based on the region; c) Personnel working in partnerships based on the region; d) turnover of partnerships based on the region.

${ }^{\mathrm{v}}$ The Health Index per Concelho is the aggregation of four indicators with the same weighting, namely: a) Number of doctors per 1.000 inhabitants; b) Number of Chemists per 10.000 inhabitants; c) Nursing personnel per 1.000 inhabitants; d) Number of beds per 1.000 inhabitants.

${ }^{v i}$ The Housing Conditions Index per Concelhois the aggregation of eleven indicators with equal weighting in eight areas, namely: a) Accessibility: \% classic dwellings owned by occupants, used as a permanent residence, according to purchasing expenses over 199,51€ and \% classic dwellings occupied as a permanent residence with a rent over 149,63 €; b) Housing Deficit: normal occupation index; c) Sheltering Conditions: \% Classic family dwellings; d) State of Repair: \% Buildings in a fair state of repair as regards infra-structures; e) Existing equipments: \% Family dwellings used as a permanent residence, with electricity, water, water-closet, heating and bath; \% Family dwellings used as a permanent residence with kitchen or Kitchenette; \% Buildings served by urban solid waste collection; f) Sewage collection and disposal: \% Family dwellings used as a permanent residence with water-closet and connect ed to the sewage collection and disposal system; g) Water Supply: \% Family dwellings used as a permanent residence with water supplied by the ; h) Vacant dwellings: \% Family vacant dwellings.

${ }^{\text {vii }}$ To reveal data concentration in order to effectively group them into clusters (or conglomerates) according to their homogeneity. (authors' translation).

viii Assuming that if a variable discriminates much among clusters, its variability (given by the Cluster Mean Square) will be high among clusters and low within its own cluster (obtained through the Error Mean Square). Thus, variables with a higher Cluster Mean Square and lower Error Mean Square are the ones which better define the clusters for they have a higher F value [11].

${ }^{\text {ix }}$ Since we wanted to perform mean multiple comparisons we did a posteriori tests to find out which of the mean pairs were different using Tukey's and Bonferroni's Post-Hoc tests.
} 